\title{
HET I5 VOLKSHUISHOUDKUNDIG CONGRES
}

GEHODDEN TE OREEELD VAN DEN 17en TOT DEN 19en ADGUSTOS 1874.

(Vervolg van blz. 435).

De tweede dag van hot Congres was uitsluitend aan het behandelen van spoorwegkwestiën gewijd. Bezitten deze voor ons land ook al niet het groote belang, dat zij voor Duitschland hebben, waar de spoorwegen toch bijna de eenige groote middelen van verkeer in het binnenland zijn, voornamelijk in die landstreken, die niet door groote rivieren doorsneden zijn, toch kan men niet zeggen, dat de daar bebandelde rraagstukken voor ons geheel van belang ontbloot zijn. De vraag toch: aanleg door den Staat dan wel door particulieren, is ook bij ons te lande, hoewel door den Staat een groot deel der bestaande spoorwegen aangelegd is, nog viet ten volle beslist, integendeel zou men wel kunnen zeggen, dat, door het overdragen van de exploitatie aan particulieren, het beginsel nog niet zuiver is uitgemaakt. Verder heeft men hier te lande ook nog niet naauwkeurig onderzocht, welke de verhouding moet zijn tusschen de aanleg- en de exploitatiekosten, zooals er dan ook nog vele andere belangrijke punten zijn, op spoorwegen betrelking, hebbende on ook voor ons land van gewigt, die eene nadere bespreking overwaardig zijn, vooral met het oog op het van dag tot dag toenemend verlangen der afgelegen oorden des lands, om ook in het bezit der communicatiemiddelen te komen, die tot nu toe slechts aan weinige plaatsen ten deel mogten vallen.

Reeds op het Congres te Weenen in 1873 hadden de spoorwegen een onderwerp van debat uitgemaakt; het afgeloopen jaar had echter, zoowel door hetgeen er al zoo omtrent de vele knoeijerijen bij de spoorwegconcessiën bekend is geworden, als door de in den loop dezes jaars verhoogde spoorwegtarieven, het vragstuk eerst regt aan de orde van den dag gesteld. De heer Baron von Kübeck, Raad ran legatie te Weenen, had zich belast met de inleiding 
van het onderwerp, namelijk de berekening der kosten van aanjeg en exploitatie der spoorwegen en van hare wederzijdeche verhouding. Volgens hem was het noodig, om voor den aanleg van alle spoorwegen wetenschappelijke regels te vinden, die tot basis zouden kunnen strekken bij het bepalen van bet voor aanleg en exploitatio noodige kapitaal, opdat riet alleen de ondernemers, maar ook het publiek daardoor gebaat worden. De referent toonde aan, dat er eigenlijk drie klassen van spoorwegen zijn: $1_{0}$ zulke, die het internationale verkeer tusschen twoe zeeën en groote bandelsplaatsen bevorderen; $2_{n}$ spoorwegen, die de eerstgen oemden met elkâar of met afyelegen plaatsen in verbinding brengen; $3^{\circ}$ buurt-spoorwegen. Het spreekt van zelf, dat een en ander invloed uitoefent op de kosten van aanleg, want van den aard van den spoorweg zal het afhangen, of de annlegkosten grooter of kleiner zullen zijn, of men b. v. om de regte lijn te handhaven, tunnels maken, over rivieren bruggen leggen zal, dan wel of men omwegen zal kiezen, ten einde de aanlegkosten te verminderen. De beer von Kübeck wees verder op de annlegkosten, die bij tot 21 verschillende rubrieken bragt en op de exploitatiekosten, die gewoonlijk minder snel toenemen dan het verkeer, terwijl de toeneming van beide een noodzakelijke grens heeft. Het zal nu noodig zijn, om de wetten op te sporen, volgens welke de toeneming van het verkeer voor een bepaalden weg zal plaats hebben. Een mathematicus, Prot. Launhardt in Hannover, heeft deze wet in eene formule gebrägt; zijn door-voorbeelden opgehelderd onderzoek toont aan, hoe belangrijk het is, de vaste wetten der meetkunde ook op de volkshuishoudkunde toe te passen, waardoor men ook op het gebied der spoorwegen niet langer zal noodig hebben in den blinde rond te tasten. Het zal pooreerst noodzakelijk wezen, de lijn aan te wijzen, zooals de handel dien noodig beeft, en vervolgens komt eerst de techniek ter sprake; het eerste immers is doel, het laatste middel. De Amerikanen hebben dit het eerste ingezien en dit denkbeeld ook verwezenlijkt, ofschoon zij zich ook daarbij to zeer door hun zoogenaamden praktischen blik hebben laten leiden, zooals ait de in Pensylvanië, in de petroleumstreek, zangelegde spoorwegen blijkt. Hoe dikwijls beeft men zich niet bij den aanleg van spoorwegen door de eischen van de strategie laten leiden, of wel zich aan de wenschien van particulieren eu gemeenten gestoord; somtijds was ook het vermoedelijke verkeer; dat meh zich vah de spoorwegen beloofde, de eenige rigtenoer zonder daarvoor de minste zekerbeid te bezitten. Juist daarom, 
meende hij, was het noodig, dat bet Cougres voor de bepaling van de rigting der spoorwegen (het tracé) grondslagen aanbeval, door de wetenschap geconstateerd. Daarmede hangt tevens de tarief. kwestie te zamen on de vraag, of het-doelmatiger is, dat de Staut spaorwegen aanlegt, dan wel particulieren dit doen. De laatste trachten natuurlijk, ten einde een hoog dividend te verkrijgen, de tarieven zooveel mogelijk te verhoogen, de Staat echter heeft niet noodiy dividenden uit te betalen, het is voldoende, als de rente van het aanlegkapitaal, de amortisatiepremie en de exploitatiekosten gedekt worden. Vermits het evenwel niet mogelïk en zelfs niet raadzaam is, bij den tegenwoordigen stand van het spoorwegwezen, het particuliere initiatiof 'geheel te vernietigen, ware het te wenschen, dat door de wetgeving zekere, door de wetenschap erkende, beginselen vastgesteld werden voor de bepaling van de rigting en den aanleg van spoorwegen, gelijkelijk voor allen verbindend, zoowel voor den Staat, als voor bijzondere ondernemers. Wel is waar heeft men in den laatsten tijd concessiën verleend tot het aanleggen van concurrerende apoorwegen, maar daarmede is bet doel niet bereikt; want de concurrenten hebben spoedig met elkaâr gemeene zaak gemaakt, zoodat men, in stede van met ééne enkele maatschappij, in het vorvolg met een anneengesloten phalanx van maatschappijen to doen kreeg, die elkaâr wederkeerig tegen mogelijke tekorten in de inkomsten verzekerden. Daurom zou bet wenschelijk zijn, dat de Staat als concurrent tegen de particuliere spoorwegmaatschappijen optrad. De concurrentie zal altijd kans van slagen hebben, de Staat, heeft immers geene kosten voor het verschaffen van het kapitaal, de renten voor dit kapitaal tot dat het werk gereed is, (interkalaryinsen) vallen insgelijks weg. Verder werkt de Staat als concurrent, door zijn grootore magt en het overwigt zijner souvereiniteit, derhalve door zijn crodiet en zijn belang, dat identisch is met dat van alle burgers, zeer weldadig op de vaststelling der tarieven en dwingt door zijn voorbeeld zijne concurrenten om dezelfde tarieven an te nemen; eindelijk krijgt hij, en dit voordeel is niet gering te achten, op die manier een geschikt personeel, dat de handelingen der particuliere maatschappijen kan onderzoeken en daarop toezigt uitoefenen: dat toch is bij, als Staat, ten opzigte der middelen van verkeer verpligt. In Duitschland, Frankrijk, Belgie en Nederland is dit gemengde stelsel algemeen aangenomen en werkt ook daar zeer goed. In Engeland heeft men zelf het stoute plan opgevat, met de overschotten der staatsinkomsten langzamerhand de par- 
ticuliere spoorwegen roor den Stant in te koopen, wat dnor de slechte balanse'u van vele groote spoorwegen gemakkelijk schijnt te worden. Ten slotte komt de heer von Kübéck tot de vraag. in boeverre het doenlijk zal zijn, de kapitalen der verschillende epoorwegondernemingen te amortiseren. Hij wijst onder anderen op Oostenrijk, waar in te nieuwe concessiën, die voor eene tijdruimte van hoogstens 90 jaren gegeren zijn, bepaald is, datjaarlijks een zeker deel van het kapitaal moet geamortiseerd worden, waarvan het gevolg zal zijn, dat de spoorwegen, aa dien tijd, aan den Staat vervallen, die dan alleen voor onderhoud en exploitatiekosten te zorgen zal hebben, zoodat de personen- en goederentarieven op een minimum zouden kunnen worden teruggebragt, voldoende voor de genoemde uitgaven en voor het vormen eener reservekas tot het aanleggen van nieuwe wegen, of wel om een deel uit te maken der gowone staatsinkomsten.

$\mathrm{Hij}$ stelde derhalve de volgende resolutie voor:

10. Vermits bet eene volkshuishondkundige wet is, dat de bewezen diensten in verhouding tot elkaâr staan moeten, is het noodzakelijk; het roor een spoorweg besteed anleykapitaal in overeenstemming te brengen met het nut, dat men daarvan trekken wil, omdat slechts dan bet door de aandeelhouders voor het werk verstrekte kapital aan de bevolking ten bate komen en op die manier het beoogde doel bereikt worden zal.

20. Het is de taak der Regering te zorgen, dat door wetten worde bepaald, dat bij den aanleg van spoorwegen, in de eerste plaats op de eischen van handel en verkeer van de streken, waar die spoorwegen zullen aangelegd worden, gelet moet worden, en dat eerst daarna de, technische uitvoering mag in aanmerking komen.

3o. Het is in het algemeen belang, om de hierboven aangevoerde motieven, dat de Staat als concurrent optreedt op het gebied van den aanleg en de exploitatie der spoorwegen.

40. Om de spoorwegen volkomen aan hun doel te doen beantwoorden, moet de térugbetaling van het aanlegkapitaal zooveel mogelijk bevorderd en bespoedigd worden. Bij iedere spoorwegconcessie moest derhalve eene amortisatiepremie vastgesteld worden, waardoor de delging van het aanlegkapitaal binnen een bepaald aantal jaren verzekerd is. Het zou tevens een punt van overweging kunnen uitmaken, of niet een deel der buitengewone inkomsten in gunstige jaren, in stede van het dividend te verhoogen, tot eene grootere amortisatiepremie gebruikt moest wor- 
den, ten einde de terugbetaling van let aanlegkapitaal te verhaasten.

Aan het debat over deze kwestie werd slechts door twee sprekers deel genomen, namelijk de bearen Dr. Rentzach van Dresden, die als gewezen spoorwegdirecteur met de kwestie meer van nabij bekend was en Dr. Jalius Faucher, de bekende redacteur van het Vierteljahrsschrift. De eerste toonde o. a. aan, hoe groot de. kosten der spoorwegexploitatie zijn, hoe b. v. om 20 pCt. levende last te vervoeren, $80 \mathrm{pCt}$. doode last voodig zijn, hoe verder de ledig staande wagens even goed van de atmospheer enz. te lijden hebben, dus afslijten, als diegenen, welke in exploitatie zijn. $\mathrm{Hij}$ was bet in het geheel niet eens met den heer von Kübeck, die voor de staatswegen geijverd had, omdat men aan de particulieré spoorwegen veel meer te danken had, wat betreft de ontwikkeling der middelen van verkeer, dan aan de stantsspoorwegen. De laatste hadden ook een aanvang gemaakt met het verboogen der tarieven. Hij voor zich hield het er voor, dat eene industrie van staatsspoorwegen nog nooit groote resultaten had opgeleverd. Hij wilde zich in deze kwestie niet te zeer door do openbare meening laten leiden, omdat die in de laatste jaren in betrekking tot dat onderwerp nog al eens veranderd was, dat deze nu wel voor staatsspoorwegen zich verklaarde, maar misschien binnen vijf jaren w̧eer anders uitspraak zou doen. Wel is waar zou, door het veranderen van de particuliere in staatsspoorwegen, een groot kapitaal vlottend worden en in omloop komen, maar dit geschiedt tegenwoordiy ook door de dividenden. De heer Rentzsch wijdde ook nog enkele woorden aan een punt door den beer von Kübeck besproken, namelijk de kosten der aanechaffing van het voor particuliere spoorwegen benoodigde kapitaal en kwam daardoor van zelf op de zoogenarmde Grindungskosten. Hij gaf toe, dat daarin buitensporigheden hadden plaats gegrepen (allen dachten hierbij natuurlijk aan de merlswaardige onthullingen van den moedigen Lasker), maar hij berreerde toch, dat, nu de concessie niet gegeven worlt, tenzij bet kapitaal ten volle aanwezig zij, de bankiershuizen, die de risico dragen, ook wel daarvoor eene voldoende premie mogten genieten. Hij stelde, op grond van cen en ander, en in aanmerking genomen, dat de zaak nog niet voor eeno beslissing rijp was, voor, dat men de resolutie van den heer von Kübeck naar eene commissie zoude verwïzen, ten einde deskundigen daarover te raadplegen en in een volgend congres rapport uit te brengen. Door den heer Faucher werd echter teregt op- 
gemerkt, dat, hoe belangrijk ook de mededeelingen van den heer von Kübeck geweest zijn, hij zich echter niet aan het programma gehouden had, dat het, vooral met het oog op de vraug of stdatsdan wel particuliere spoorwegen de voorkeur verdienen, zeer belangrijk is, de kwestie der annleg- en exploitatiekosten te onderzoeken. In Engeland maken de kosten vodr het materieel geen deel der aanlegkosten uit, maar worden door de uitgifte van debentures (vlottende schuld) gedekt. Hij wees door een voorbeeld aan, hoo men, hetzij de aanleg-, bietzij do exploitatiekosten verboogen kan, wanneer men drie steden met elkaâr verbindt, door een driehoek of wel door een gemeenschappelijk middelpunt te kiezen, b. v. Amsterdain-Rotterdam-Arnhem: is het nu verkieslijker: Amstierdam met Rotterdam, Rotterdam met Arnbem en Arnhem met Amsterdam to verbinden, dan wel Jtrecht als middelpunt te nemen, dit te verbinden met Amsterdam en dan Utrecht te makon tot de top vah een drieboek, waarvan de lijn Rotterdam-Arnbem de basis zou zijn? door het eerste te dón zoude men de aanlegkosten, door het tweede de exploitatiekosten vermeerdgren. Ook hij bespreekst de brochure van professor Lauhhardt van Hannover: die commercielle Tracirung der Verkehrswege, die daarin tot de conclusie kont, dat Staatsannleg boven aanleg door particulieren te verkiezen is, omdat de Staat voornamelijk de voortdurende rente en het altijddurende nut op het oog heeft, terwijl de particulieren slechts op de rente van de eerstkomende 40 of 50 jaren letten, omdat daardoor de beurswarde der aandeelen bepaald wordt. Op grond van een en ander verklaarde bij zich ook voor eene verwijzing der zaak naar eene commissie. Op voorstel van Dr. Alexander Meijer werd dan ogk besloten, de zaak an eene commissie op te dragen, die in eene volgende bijeenkomst van het Congres daarover rapport moet uitbrengen. Een voorstel van twee andere leden van het Congres, dat het Duitsche Rijk alle particuliere spoorwegen overnemen, en de aandeelhouders door toekenning eener vaste rente schadeloos zou stellen, werd eveneens naar die commissie verwezen.

De tarieflswestie kwam vervolgens ter sprake. Het vraugpunt der tariefverhooging van vrachtgoederen beeft in de twee laatste jaren de genoederen van de Duitsche handelaren en fabriekanten in beweging gebragt, omdat het zoo naauw zamenhangt met de prijsbepaling der waren en voor menigen taks van nijverbeid eene levenskwestie is, terwijl het twijf 
de concurrentie met andere landen zou kunnen volhouden, zoo de productiekosten, door de verbooging der spoorwegtarieven, zullen stijgen. Toen, na het eindigen van den Franscb-Duitschen oorlog, handel en industrie in Duitschland spoedig een hoogere vlugt namen, dan men in de onmiddellijk aan den oorlog voorafgaande jaren bad waargenomen, toen werd er reeds, boofdzakelijk door hen, die in hunne boedanigheid van aandeelbouders, direoteuren, toezigt-ẹommissarissen bij hooge dividenden, tantièmes enz. belang hadden, op verhooging van de spoorwegtarieven aangedrongen. In den zomer vah 1872 was er in Pruissen zelfs sprake van het verlagen der tarieven voor het vervoer van personen, terwijl daarentegen de vrijdom van bagaadje (gewoonlijk 25 Kos. per persoon) zou ophouden. De directiën der staatsepoorwegen, deswege om haar oordeel gevraggd, hebben zich toen eenistemmig ten gunste van dit plan verklaard. Van dit plan kwam evenwel niets, maár wel werden or in 1873 stemmen gehoord ten behoeve eener verhooging der tarieven van vrachtgoederen, op grond, dat dit allernoodzakelijkst geworden was, ten gevolge der verhooging van de loonen, van de prijzen pan steenkolen en ijzer. De spoorwègondernemingen, de reusachtigste naamlooze vennootschappen van den tegenwoordigen tijd, bezitten niet alleen een groote magt door het vervoer van personen en gueduren, dat zij voor bet grootste gedeelte in hare handen hebben, waardoor zij aldus het omzetten der vơortbrengzelen bevorderen, of tegenwerken kunnen, mdar ook door de grootste kapitalen en het belang der vele aindeelhouders, die tot zelfs in de hoogste kringen der maatschappij wörden aangetroffen, oefenen zij een grooten invioed uit. Dit belang wordt nog grooter voor ben, die zoo gelukkig zijn, als directeuren of als commissarissen bij de hoogst mogelijke opbrengst der spoorwegen bet meest geinteresseerd te zijn. En dat het deel, dat de commissarissen dikwijls ontvangen (waarsehijnlijk voor den moeijelijken arbeid!) niet gering is, blijkt uit het feit, dat bv. de commissarissen van de lijn Berlijn-Anhalt onlangs geacht werden eene jaarlijksche tantième van $10000 \mathrm{Thlr}$. te trekken, behalve het kostelooze vervoer op den spoorweg en andere voordeeltjes, en dat het inkomen van den voorzitter van den Raad van toezigt op 30 à 40000 Thlr. werd gesebat $\left({ }^{*}\right)$. Om nu-verzekerd te zijn van den steun der Regering, behoefde men slechts

$\left.{ }^{*}\right)$ Zie het merkwaardige artikel van F, Perrot. Die Erhöbung der Eisenbahntarife. Im nenen Reich 1874, No, 23. 
invloedrịk" personen met dergelijke sinecures te begiftigen en men kon zich overtuigd houden steeds, waar het noodig was, een geopend oor voor zijne eischen te vinden. Wasr men nu dikwijls de hoogst geplaatste personen uit alle kringen, zoowel uit die van het bestuur van land, provincie en stad, als uit die der geldmannen, van den adel, van handel en nijverheid, als leden van die Raden van toezigt zag fungeren, daar was het voorzeker niet te verwonderen, dat de geprojecteerde verhooging der spoorwegtarieven niet dien tegenstand rond, als zij eigenlijk wel verdiende, ja daarin meende men ook de reden te moeten vinden van den geringen, ten minste lauwen, tegenstand van handel en industrie tegen een maatregel, die hunne belangen toch wel in de eerste plaats betreft. Toen nu, ten gevolge van de financieele krisis op de Weener en Berlijner beurzen in 1873 , de spoorwegaandeelen belangrijk gedaald waren, toen ten gevolge van de algemeene malaise, waaronder handel en nijverheid in dit jaar gebukt gingen, ook de bruto inkomsten der spoorwegen aanmorkelijk minder werden, toen eindelijk, dien ten gevolge, ook de dividenden en tantièmes den terugslag van een en ander ondervonden, toen had men gewonnen spel en de ver. hooging der spoorwegtarieven was een besloten zaak. De oppositie tegen dien maatregel van de zijde van den Rijkskanselier, van de zijde van den Pruissischen Minister voor Handel en Nijverheid was overwonnen en het besluit werd genomen, om met $1 \mathrm{Julij}$ 1874. (later werd dit tot 1 Januarij 1875 uitgesteld) de tarieven op alle spoorwegen met 20 pCt. te verboogen. In bet jaar 1873 was ook in Duitschland een zoogenaamd Reichseisenbahnamt in bet leven geroepen, ann welke de meeste der functiën, die tot nu toe door de verschillende regeringen uitgeoefend zijn geworden, werden opgedragen. Maar tocb, en ook daarop is reeds gewezen geworden, bad niet de Bondsraad over het tariefwezen eigenmagtig te vervoegen, maar behoorde dat, ingevolge de duidelijke bepaling van art. 45 der Duitsche Grondwet, tot de attributen van het Duitsche Rijk, dus in gezonden, constitutionnelen zin tot de taak van den Rijksdag; aan hem beboordo het toezigt over het tariefwezen, waarbij voor de meest mogelijke gelijkheid in, en verlaging van de tarieren moest worden gezorgd. Wel is waar is later door de vele kamers ran koophandel in den Pruissischen Staat en door talrijke vereenigingen tegen de verbooging van de spoorwegtarieven geprotesteerd geworden, tot $\mathrm{nu}$ toe echter zonder 't minste resultaat, ofschoon toch een der hoofdmotieren, weshalve men de verhooging verlangde, sedert de laatste maanden vervallen is, 
nadat de prijzen van ijzer en steenkolen en de arbeidsloonen aanmerkelijk zijn gedaald.

De vraag, welk stelsel men bij de tarieven der vrachtgoederen tot grondslag moet nemen, had ook reeds in de laatste jaren het onderwerp van bespreking in vele vergaderingen uitgemaakt; ja zelfs had de Kamer ran koophandel en fabrieken te Praag, in eene memorie aan den Oostenrijkschen Minister van Koophandel voorgesteld, door het uitschrijpen van een prïspraag, bet stelsel te vinden, dat, èn eenvoudig was, èn de eischen van het verkeer en de belangen van de spoorwegondernemingen het best bevredigde. Ook op het Volkshuishoudkundig Congres te Weenen in 1873 had men de spoorwegkwestie reeds tot een punt ran debat gemakst, de vraag, of men aan het waggon- on collotarief niet de voorkeur moest geven, was toen ook behandeld geworden. Sedert dien tijd waren er nog andere stelsels betreffende de wijze van tarifering der rrachtgoederen ter sprake gekomen, namelijk dat van Brunswijk en dat ran Elzas-Lotharingen. Door het laatstgenoemde, dat het zuivere waggon- en collotarief het meest nabij komt, verstaat men dat tarief, dat, nevens het waggon- en collotarief, ook nog het onderscheid kent tusschen gedekte en ongedelste wagens, en hier weer een onderscheid of het prachten zijn van 100, dan wel ran 200 ctr.; daardoor ontstaan de klassen A 1 en 2 en B 1 en 2; verder zijn nog eenige bijzondere tarieven ingevoerd pour steenen, metalen enz. Het Brunswijksche stelsel heeft niet het onderscheid tusschen gedokte en ongedekte wagens; hier beeft dus de vervrachter niet, zooals in den Elzas, de keus tusschen do beide soorten van vervoer, uithoofde de spoorwegondernemingen zeggen: door dit onderscbeid lijden wij nadeel, omdat: is het schoon weder, allen dan ongedekte wagens verlangen en is het slecht weder, dan wil iedereen gedek te wagens. Er zijn dus, volgens dit stelsel, ook wel gedekte en ongedekte wagens, maar de spoorwegonderneming heeft hier de keus; daarenboven heeft men in dit stelsel nog 11 bijzondere tarieven, zoodat, wanneer men die rekent bij de andere onderverdeelingen, de rrachtgoederen wel in $26 \mathrm{klassen}$ gerangschikt kunnen worden.

Op hetzelfde Congres te Weenen was de volgende resolutie aangenomen: in ieder geval zijn do gebreken van het spoorwegwezen slechts uit den weg to ruimen door de ontwikkeling der rrijheid van het verkeer op die spoorwegen, en het einddoel noet zijn, de opheffing van het monopolie des vervoers, dat de spoorwegoudernemingen tot nu toe bezitten. 
Sedert dit besluit, van het congres was er een werk verschenen, van een Triëster journalist Dr. Alexander ron Dorn, (*) waarin voornamelijk aangetoond wordt, dat het monopolie van het totale spoorwegvervoer, in handen van weinige groote onderuemingen, slechts ten nadeele van de algemeene belangen der volkshuishouding kan strekken. $\mathrm{Hij}$ beweert verder, dat het ideaal, dat men noet trachten to verwezenlijken, bestaat in de rrijheid van het gebruik der spoorwegen ten behoeve van het algemeen verkeer, omdat het niet noodzakelijk is, dat juist de eigenaar van den weg de eenige zijn moet, die het verroer op dien weg bewerkstulligt. Hij wil dus, dat de spoorwegeigenaar niet langer bet uitsluitend regt vau het vervoer bezițte, naar dat de spoorwegen als 't ware publieke straten worden, warrvan iedereen, onder de noodige wạrborgen, voor de veiligbeid en tegen schadeloostelling, gebruik han maken. De schrijver is, uit den aard der zask, een voorstander vun stastsspoorwegen, hij wil, dat deze, even als alle andere wegen, den Staat toebehooren, omdat slechts daardoor dit groote communicatiemiddel van den tegenwoordigen tijd de regtmatige wenschen van het publiek, dat daarvan moet gebruik maken, kan bevredigen.

Het was dus wel te voorzien, dat de behandeling der tariefkwestie de algemeene belangstelling zou opwekken en asn dit onderwerp werd dan ook voor het grootste gedeelte de tweede congresiag gewijd. De heer M. Broemel, Secretaris van den handelsstand te Stettin, had zich met het referaat belast. Het kan natuarlijk niet in onze bedoeling liggen, om van hetgeen door hem gezegd werd, uitvoerig verslag te geven, daar zulks de grenzen van een tijdschriftartikel zou overschrijden.

Wij willen er ons dus slechts tae bepalen, om uit het belangrijkste van zijn betoog het een en ander aan te stippen. Hij meende, dat men diende na te gaan, welke houding men moet aannemen tegenorer de besluiten van den Bondaraad ten oprigte van de verhooging der tarieven. De hoofdkwestie is, of men aan de spoorwegondernemingen onbeperkte vrijheid zal geven, om bare tarieven naar willekeur in te rigten, dan wel of dit slechts onder nadere goedkeuring van den Rijkswetgever of van de bijzondere regeringen zal mogen geschieden. Hij gaat van het beginsel uit, dat er van het kiezen ran een stelsel geen sprake meer kan zijn, nadat men op het Weener congres in 1873 het waggontarief voor het ver-

(*) Alexamuler Dorn, Die Aufguben der Eisenbahnpolitik. Berliu 1874. 
kieslijkste had verklanrd. Hij drukt er voornamelijk op, dat het groote gebrek hierin gelegen is, dat de spoorwegonderneming roerman en expediteur te gelijk is. Die beide functiën moeten niet op dezelfde wijze worden uitgeoefend. Juist daardoor zijn de spoorwegen dan ook, wat betreft het ambod hunner diensten, aan de vrije martschappelijke wetten onderworpen met opzigt tot vraag en aanbod; de prijzen van het vervoer moeten an den afzender der goederen de mogelijkheid laten, door het verzenden zijner waren een roordeel te bebalen, dat is dus het maximum van den prijs, het eenige rigtsnoer voor den vrager, terwijl het minimum van den prïs, even ais van andere zaken, niet beneden de productiekosten der onderneming gaan kan. De omstandigheid, dat er concurrentie bestaat van andẹre spoorweglijnen, doet er niets toe af, het eenige gevolg dasrvan zal zijn, dat de spoorwegondernemingen grootere moeite zullen aanwenden, om bepaalde vracbten te krijgen; de transportkosten kunnen echter nooit beneden den productieprijs dalen, ten minste niet op den duur. Hij wil niet ontkennen, dat het monopolie, dat de eigenaar van den spoorweg bezit, ook zeker op de prijsbepaling der vrachten invloed zal uitoefenen; maar toch toont bij door eene vergelijking met het tarieferingsbeginsel der groote stoombootlijnen aan, dat het dikwijls overdreven is, over de willekeur der spoorwegmaatschappijen te klagen, want ook de stoombootondernemingen kennen verminderde seizoentarieven, ook bij de\%e is er sprake vąn vermin. derde prïzen voor groote rraebten of bepaalde artikels, væn gelïkheid van vrachtprijzen voor verder afgelegen plaataen met dieder tusschenstations. Hij beweert, dat dit geheel oveneenkomstig is met de theurie, waardoor de, met opzigt tot het verkeer geldende, wet der prijsbepaling bevestigd wordt, dat, bij ondernemingen tot het vervoer -ran goederen, ook uit een zuiver handelsbelang, prijsverminderingen daar het eerst en het meest plaats vinden, war de groote centrale punten verbonden worden; de graad van bet verkeer en de beteekenis der plaatsen zullen natuurlijk tot maatstaf strekken.

Hij houdt rol, dat de invloed van den Staat op bet tariefwezen zooals dit in verschillende Duitsche landen bestaat, nadeelig is en dat juist de grootere vrijheid, om, ṇaar gelang qan omstan. digheden, de tarieven te verhoogen of te verlagen, gunstig op bet tariefwezen heeft gewerkt. Maar ook de indirecte invloed van den Stant op de prijsbepaling van het transport, door het toezigt, dat hij uitoefent over den weg, de gebouwen, het materieel, be- 
lemmert de ondernemingen dikwijls in de wijze van het aanbod harer diensten. Hoe dikwijls rijzen er geen klagten, dat de spoorwegen aan de regtmatige eischen van het publiek niet volduen! En hoe zullen zij dit kunuen, zoo zij, door de bepaling van de prijzen, waarvoor zij moeten vervoeren, als 't ware belemmerd worden in bet ruimer asubieden hunner diensten? Zou hier niet, even als operal in het maatschappelijk verkeer, de vrijheid der beweging de conditio sine qua non zijn voor den goeden gang der zaken?

Maar ook de wijze, waarop de spoorwegen hun bedrijf uitoefinen, werkt nadeelig op bet tariefwezeu. De spoorwegen zijn de grootste ondernemingen, die er ooit bestaan hebben; zij schijnen echter to bewijzen, dat het beginsel, hoe grooter de exploitatie des to voordeeliger werkt zulks op de kosten, slechts betrekkelijk waar is. Het schijnt in der daad, dat iedere uitbreiding van de arbeidsverdeeling en iedere vermeerderiug ran het aanlegkapitaal niet altijd betere resultaten voor de voortbrenging zallen hebben, maur dat hare gunstige gevolgen dusr zullen ophuudeu, waar bet eeue onmogelijkheid wordt, wegens de uitgebreidheid der zaak, de leiding daarvan in ééne band te concentreren en op bijzondere omstandigheden acht te slaan. De stoombootondernemingen Lebbeu in dit opzigt eene betere organisatie. Haar ter zijde staan vele agenten, die er belang bij hebben, vrachten voor de under. neming te verkrijgen en die door hunue praktische exvaring de directio op mogelijke gebreken opmerkzaam maken. Geheel anders is het bij de spoorwegondernemingen: daar kent men slechts ambtenaren, die de voorschriften der directie stipt hebben op te volgen, zouder zich de minste verandering te mogen veroorloven; zij bebben ook niet het regt, om in byzondere gevallen van het vastgestelde tarief af te wijken. Het is dan ook daarom vooral noodzakelijk, dat or eene verandering teu deze worde ingevoerd, namelijk scheiding tusschen het bedrijf van onderuemer van verroer en but bedrijf van expediteur, - Hij stelde daarom eone resolutie voor, die wij zoo aanstonds zullen meêduelen, daar er ten gevolge van bet debat nog een belangrïk amendement in opgenomen is geworden.

De beer Dr. Hammacher, lid van den Pruissischen Landday, had zich namelijk tot taak gesteld, om do beginselen van Dr. Alex. von Dorn, warop wij reeds met een enkel woord hebben gewezen, te verdedigen; hij stelde voor in de resolutio den wensch op te nemen, dat door de wetyering de beginselen zouden worden vastgesteld, volgens welke het een anderen ondernemer zal geoorloofd zijn, gebruik te maken van-een spoorweg en zijue ex- 
ploitatiemiddelen, terwijl de schadeloosstelling op wettelijken weg zou moeten worden bepaald.

De beer Hammacher ging daarbij van de volgende redenering uit: de spoorwegen bebben aan onteigening hun ontstaan te danken; hetzelfde algemeene belang, wat ten hunnen behoeve de onteigening vorderde, kan ook weer eene onteigening van het gebruik, expropriatio usus, noodzakelijk maken. Hij meende, dat zoodanige concurrentie van spoorwegondernemingen op denzelfden weg, onder voldoende waarborgen voor de veiligheid, allerheilzaamst zou werken. Hij toonde de mogelijkheid daarvan aan, door met eenige voorbeelden te wijzen, boe in Pruissen eenige lijnen door staats- en particuliere spoorwegen gebruikt worden. Voor dit denkbeeld schijnt men, volgens den heer Hammacher, tegenwoordig zelfs in Engeland veel sympathie te hebben, terwijl het tevens eene groote besparing van kapital zal ten gevolge bebben, wanneer het niet meer noodig zal zijn, dikwijls nieuwe lijnen aan te leggen, om verschillende plaatsen met elkander te verbinden, waar men, voor het grootste deel, vau denzelfden weg en dezelfde gebouwen gebruik zoude kunnen maken. Wij zuuden, voor wat ons land betreft, kunnen verwijzen uaar de wet ran 21 Aug. 1859 (Stbl. $n^{0} .98$ ) houdende bepalingen omtrent het gebruik der spoorwegen, waarin men in art. 3 leest, dat de ondernemers van spoorwegen verpligt zijn te gedoogen, dat aan den spoorweg, waarover hunne dienst loopt, spoorwegen door anderen aan te leggen, zich aansluiten, en dat die weg, door zoodanige wegen worde doorsneden, terwijl art. 4 bepaalt, dat de ondernemers insgelijks verpligt zijn te gedoogen, dat de weg waarover hunne dienst lonpt, ten behoeve van andere spoorwegdiensten worde gebruikt. De volgende alinea's van dit artikel vermelden de wijze, hoe de schadeloosstelliug en het gemeenschappelijk gebruik van den weg zullen worden geregeld. Is er dus bij ons te lande gezorgd, dat geen spoorwegondernemer ten nadeele van het algemeen, het aanleggen van andere lijnen zal kunnen dwarsboomen, toch is daarmede slechts teri deele het doel bereikt, wat de heer Hammacher ons, in navolging van het geschrift des heeren von Dorn, voor oogen stelde. De ondernemers worden immers niet genoodzaakt, ook hunne gebouwen en andere exploitatiemiddelen tegen schadeloosstelling ten gebruike of te staan. Ware zullss het geval geweest, dan ware men, bij den aunleg der staatsspoorwegen, niet blootgesteld geweest aan de plagerijen der Centraal-en Rijuspoorwegmaatsciıappijen.

ECON. 1875. 
Door het congres werd de volgende resolutie angenomen, welke reeds door de $N$. Rott. $C t$ medegedeeld is in haar nummer van den 29 Oct. dezes jaars (op verzoek, zooals zij meldde, ten einde van nut te kunnen zijn, bij de aanataande discussie over de wet op de spoorwegdiensten.)

I. De spoorwegen kunnen zich bij het vaststellen hunner tarieven niet onttrekken aan den invloed van vraag en aanbod, omdat hunne vervoerprijzen zoowel afhankelijk zün van — als terugwerken op bet bloeijen of kwijnen van particulieren handel en van nijverheidsondernemingen, ten gevolge der eventueele prïzen der te vervoeren goederen. Alle Regeringsmaatregelen, welke, zonder dit standpunt der spoorwegen in de volkshuishouding te eerbiedigen, ten doel hebben de tarieven te regelen naar de zuivere kosten van vervoer, geven aanleiding tot het verleenen van bijzondere gunsten aan enkele takken van handel en nijverbeid. Slechts door den ondernemers van het vervoer, die zoo mogelijk niet tevens eigenaren van den spoorweg mogen zijn, zooveel mogelijk onbeperkte vrijheid te laten, de tarieven naar goedvinden te regelen, zijn juiste prijzen te verkrïgen.

II. De beperkingen in de vrijheid, om de tarieven te bepalen, welke an de spoorwegen door de wet of de Regering worden gesteld, en haar grond vinden in bijzondere aan de spoorwegen toegekende regten, mogen slechts zulke bepalingen bevatten, welke in het algemeen belang van het verkeer zijn. Als zoodanig kunnen alleen de volgende beperkingen beschouwd worden.

a. Het publiceeren van alle tarieven binnen een behoorlijken termijn vóór de invoering dier tarieven.

b. De gelijkmatige toepassing der gepubliceerde tarieven voor alle verzenders, waarbij echter prijsverlagingen, bij verzending van groote boeveelheden of bij regelmatige verzendingen van een of meer wagenladingen, vooral als retourrracht, niet uitgesloten mogen worden, mits deze verlagingen tijdig aangekondigd en voor alle verzenders toepasselijk zijn.

c. De vaststelling van maximum-tarieven, die zonder vergunning van de Regering niet mogen overschreden worden en die aan eene periodieke herziening zijn onderworpen.

III. $\mathrm{Bij}$ de wet moeten de grondslagen vastgesteld worden, volgens welke bet aan andere ondernemers geoorloofd zal zijn, gebruik te maken van een spoorweg en ran rijne exploitatie-inrigtingen. In die wet zouden ook de hier voor te betalen schadeloosstelliugen moeten aangewezen worden. 
Door deze resolutie werden dus de beginselen van vrijheid ook voor de spoorwegen niet verloochend, maar terens aan de Regeringen het noodzakelijke toezigt op die belangrijke vervoermiddelen verzekerd en haar invloed gehandhaafd bij de vastatelling der tarieven. Indien het immers niet te ontkennen is, dat voor de spoorwegen, als ondernemingen tot het vervoer van personen en goederen, dezelfde wetten gelden, die het voortbrengen der rijkdommen beheerschen, dan mag men toch niet over het hoofd zien, dat bet ondernemingen sui generis zijn, die alleen ten behoeve van het algemeen belang bestaan en niet uitsluitend on het voordeel der ondernemers, dat die ondernemingen alleen door het opofferen van bijzondere regten (onteigening) kunnen tot stand komen, zoodat het algemeen belang dan ook in de eerste plaats op den voorgrond moet staan. Maar nog twee andere belnngrijke beginselen werden door die resolutie vooropgesteld, namelijk 10 dat de ondernemers van het vervoer zoo mogelijk niet tevens eigenaren van den spoorweg moeten zijn, of zooals men zich uitdrukte Trennung von Traktion und Spedition en 20 vrijheid voor alle ondernemers van vervoer, om van den weg te mogen gebruik maken, of met andere worden: de spocrweg een publieke straat voor allen, het ideaal dat de toekomst zal moeten verwezenlijken. Wat het eerste punt betreft, zouden wij hiervoor als voorbeeld kunnen wijzen op de overeenkomst tusschen de Grand Central Belge en de onderneming van v. Gend en Loos, aan welke, tegen eene jaarlijksche uitkeering, de geheele expeditie der vrachtgoederen is overgedragen.

De overeenkomsten door die onderneming met de Nederlandsche spoorwegmaatschappijen om, tegen verzekering van eene bepaalde hoeveelheid vrachtgoederen, voor een lager tarief dan andere verzenders te mogen vervoeren, voldoet evenwel niet aan het beginsel van punt II $b$ der medegedeelde resolutie. - En wat het tweede beginsel aangat, de spoorweg eene publieke straat voor allen, bet is ligt te begrijpen, dat zulks eerst dan zou kunnen wordeu verwezenlijkt, als alle spoorwegen publiek domein zijn geworden.

En dat het Congres zich ook wederom bij dit onderwerp in overeenstemming bevond met de algemeene denkwijze, blijkt uit het volgende. Den 22 en 23 October jl. had te Berlijn de bijeenkomst plaats van den Duitschen Handelsdag. Ook bij die gelegenheid stond de tariefkwestic op het programma, en ook door deze vergadering werd het besluit genomen, dat men het voor een regtmatigen eisch hield, dat aan de spourwegondernemingen in ieder geval de bevoegdheid moest verleend wordun, 
om, binnen de grenzen pan het door de Regering vastgestelde maximum, vrijelijk veranderingen in de tarieven te maken, zoowel als verlaging in de speciale tarieven in te voeren en die weer volgens goeddunken op te heffen.

Het Congres had aan de nitroerige behandeling van de spoorwegkwestie den geheelen tweeden dag besteed, zoodat een ander onderwerp, dat voor dien dag op bet programma stond, namelijk de strafbasheid van bet verbreken der werkovereenkomsten, niet behandeld kon worden. En toch ware het hoogst wenschelijk geweest, ook over dit punt, hetgeen in de twee laatste jaren in Duitschland nog al druk besproken is geworden, waarvan zelfs de Rijksdag reeds eens gesaisisseerd was, het oordeel van het Congres te vernemen. Het ware zeker hoogst interessant geweest, den geestigen en scherpzinnigen Dr. Alexander Meijer zijne resolutie te hooren ontwikkelen, die hij betreffende dit onderwerp aan het oordeel van het Congres had willen onderwerpen. Deze resolutie was van den navolgenden inboud: 1 Volgens de oudere regtsbeschouwingen werd gewoonlijk de niet vervulling van aangegane verpligtingen, zelfs waar geen sehuld bestond, als een misdrijf beschouwd. Als een overblijfsel van deze zienswijze heeft zich de lijfsdwang tot in den jongsten tijd staande gebouden. Het was een voortgang der beschaving, dat dit strafmiddel, namelijk bij onwillekeurige onbekwaambeid, om de verbindtenis na te komen en bij 't leenen van geld en geldswaarde, afgeschaft werd. 20 Daarentegen is de straffeloosheid van het verbreken eener overeenkomst (contractbruch), ook bij zoodanige schuldrorderingen, wier vervulling aan den schuldenaar overgelaten is, en wier niet-vervulling op kwaden wil berust, een nadeelig resultaat van dé hedendaagschó wetgeving, hoowel door deze niet bedoeld. Daarom is het dringend noodzakelijk de wetgering op dit punt te herzien.

Ook op het Eisenacher Congres is deze kwestie ter sprake gebragt en daar is, met eene geringe meerderheid, eene resolutie aangenomen, waarin o. a. verklaard werd: dat overal, waar, door eene willekeurige verbreking eener orereenkomst, schade aangerigt is, en de verbreker die schade niet kan of wil vergoeden, op vordering van de tegenpartij, eene strafactie moet worden ingesteld.

Een ander onderwerp, dat ook tegenwoordig in Pruissen van veel belang is, namelijk de pligt voor handwerkers om herhalingscholen (gewerbliche Fortbildungschulen) te bezoeken, kon even. min ter sprake komen. De Fortbildnangchulen zelve zijn thane in 
Prui rsen aan de orde van den dag. De Regering toont zeer veel sympathie daarvoor, zij tracht deze, niet alleen met hulp der provinciale besturen, maar ook door staatsmiddelen te bevorderen. Ja zelfs van de medewerking der geestelijkheid heeft de Pruissische Minister voor Onderwijs zich trachten te verzekeren, en door het Protest. Opperconsistorie (Oberkirchenbehörde) de kerkeraden (consistoriën) in de verschillende deelen des lande doen ansporen en hen op de noodzakelijkheid van de Fortbildungschulen opmerkzasm gemaakt. Hierbij wordt van het beginsel uitgegann, dat deze school geene vak- of bandwerk- of ambachtschool is, maar dat zij bestemd is tot voltooijing en voortzetting van de algemeene volkschool. Daarbij wordt wel is waar het onderscheid tusschen landelijke en stedelijke beroepen in bet oog gehouden, maar het algemeene karakter der Fortbildungschule blijft ongeschonden. Algemeen wordt nu het beginsel vooropgesteld, dat het bezoek ran zoodanige scholen verpligtend moet gemaakt worden, terwijl ook de Pruiss. Minister Falk het verstrekken van staatshulp heeft toegezegd onder voorwaarde, dat de gemeenten bij hare verordeningen bet bezoeken van die scholen verpligtend maken. De motieven, weshalve de nieuwe schoolpligt, zooals ook de oprichting en organisatio der scholen ran Staatswege worden aanbevolen zijn de volgende: het algemeene stemregt, de strijd met het Pausdom, de socialistische woelingen en andere overwegingen maken het tot eene levenskwestie, dat de geheele volksmassa, voornamelijk on in de eerste plate de mannelijke jeugd, op een hoogeren trap van beschaving worde gebragt. Maar men kan daarbij niet rustig afwachten, wie en hoeveel er van het aangeboden onderwijs zullen gebruik maken; er moet gezorgd worden, dat allen dit doen, mogen er ook al eenigen wezen, die onwillig zijn en zich aan den dwang trachten te onttrekken. Op 15 en 16 jarigen leeftijd toch wijst de mensch nog veel terug, wat hem later berouwt, zich niet te hebben eigen gemaakt; de ouderlijke dwang ontbreekt dikwijls, ondat de ouders zelve slecht opgevoed zijn en van bet kind misbruik maken : daarom moet er staatsdwang in de plaats komen. De reeds genoemde Dr. Alex. von Dorn had betreffende dit onderwerp de volgende resolutie voorgesteld, die echter wegens gebrek aan tijd, niet in behandeling is kunnen genomen worden:

10. Het bestaan en de, in overeenstemming met den tegen woordigen tijd, verdere ontwikkeling van deu duitschen handwerkstand is af hankelijk van eene uitgebreide oprigting en het vlijtige bezoek van handwerkersherbalingscholen. Derhalve is het hoogst wenschelijk: 
1) dat de oprigting van zoodanige scholen, ouder medewerking van de drie factoren, die daarbij bet meeste belaug hebben : Staat, Gemeente en beroepsgenooten, zooveel mogelijk bevorderd worde.

2) dat van den kant der beroepsgenooten gezorgd worde voor een ruim gebruik van die scholen.

De laatste dag van het Congres was enkel aan het bebandelen der bankkwestie gewijd. Vóóraf eenige opmerkingen tot nadere toelichting van dat hoogst gewigtige vraagstuk. Sedert de Duitsche eenheid tot stand is gekomen, werd in Duitschland de behoefte gevoeld, om die eenheid niet slechts eene uitsluitend staatkundige eenheid te doen zijo, maar van haar ook in het maatschappelijk verkeer de meest mogelijke voordeelen te trekken, derhalve eenheid van wetgering, eenbeid van post-telegraaf- en muntwezen en, last not least, eenheid ran bankwezen. Het Duitsche bankwezen toch was juist het gebied, dat het meest de kwade gevolgen van het particularismus, van de staatkundige verbrokkeling bad ondervonden. De 34 duitsche banken, die allen het regt hebben, om bankbilletten uit te geven en van dit regt steeds ruimschoots gebruik maken, werden reeds lang door het publiek wet leede oogen aangezien. De bankbilletten toch, hoewel de respectieve banken uitsluitend door de Regeringen der verschillende Staten voor het eigen grondgebied concessie badden gekregen, badden zich allengskens door geheel Duitscbland een weg weten te banen, en, ofschoon niemand gedwongen was eene vreemde bauknoot aan te nemen, hadden deze zoogenaamde wilde Scheine langzamerhand het karaliter van ruilmiddel aangenomen en moesten als zoodanig wel door kooplieden en fabrieknnten worden ontrangen, terwijl ook de kleine neringdoenden en arbeiders, wilden zij hunne klandisie siet verliezen, genoodzaakt waren ze aan te nemen. Vermits zij echtor slechts inwisselbaar waren bij de banken zelve, was men wel genoodzaakt, ze aan bankiers en wisselaars tegen provisie te verkoopen. Het hạd dan ook reeds lang tot de vrome wenschen van den Duitschen handelstand behoord, eindelijk eens verlost te worden van die verscheidenheid in bet bankwezen, dat nog verergerd werd door het groote aantal papiergeld (Kassenscheine), door de verschillende Regeringen uitgegeven en als wettig betaalmiddel in de landen van uitgifte circulerende, maar dat zich ook daarbuiten burgerregt had weten te versehaffen. Wanneer men derhalve in Duitschland betalingen te doen of te ontvangen had, 
dan kon men met een staalkaart van de meest verschillende papieren betaalmiddelen, in alle kleuren van den regeuboog gedost, kennis maken.

De Regeringen van eenige Staten, bv. Baden, hadden wel van tijd tot tijd het aannemen vau die verschillende billetten verboden, maar waren alras tot de overtuiging gekomen, dat die verbedmiddelen niet konden gehandhaafd worden, ju moesten eindelijk zelve de verbodsbepalingen overtreden en die billetten in hare Kassen aannemen. Vermits nu reeds, vóór dat het Duitsche Rijk tot stand was gekomen, het plan bij den Noordduitschen Bond bestond, om het muntwezen gemeenschappelijk te regelen, had men reeds, bij de wet van 23 Maart 1870 (later ook op de Zuidduitsehe Staten toepasselijk verklaard) bepaald, dat de bevoegdheid, om bankuoten uit te geven, tot dat eene bankwet voor hel gebeele Rijk zou vastgesteld zijn, op den tegenwoordigen voet you bestaan blijven; dat na den 31 Dec. 1874 geen verlof om bankuoten uit te geven, zou kunnen verkregen worden, dan ten gevolge van eene Rijkswet, op voordragt van de Regering van het land, waar men de bank wilde oprigten, en dat dit voorscirift op de bestaande banken insgelijks toepasselijk zou zijn, voor het seval zij bare concessie wilde doen verlengen, of meer banknoten wilde uitgeven, dan haar aanvaukelijk geoorloofd was. (*) Bij de Duitsche muntwet van 9 Julij 1873 werd in art. 18 bepaald, dat met 1 Januarij 1876 al het papiergeld der Duitsche staten zal moeten: ingetrokken worden, en dat daarentegen voor eene som van 120 millioen Rijksmark (70 mill. gulden) aan Rijkspapiergeld zal uitgegeven worden, onder de verschillende staten te verdeelen, naar verhouding van 3 mark per hoofd der bevolking, waarvoor als dekking aangewezen werd de befaamde oorlogscbat van 40 mill, thaler in den Juliustoren te Spandau neêrgelegd (een fraaije waarborg, als het Duitsche Rijk eens daarmeê gaat oorlog roeren, en, hetgeen toch ook niet tot de oumogelijkheden behoort, de verliezende partij wordt.) Verder bepaalt hetzelfde artikel, dat, te rekenen van den 1 Januarij 1876, door de banken geeve billetten mogen worden uitgegeven tot een lager bedrag rian $\operatorname{ran} 100$ R. Mark. ( $\dagger$ ) Dit is de eenige bepaling, die in de

$\left({ }^{*}\right)$ Na de intrekking van het nieuwe baukontwerp in Nov. ll. heeft de Rijksdag dien termijn met één jaar verlengd.

( $\dagger$ ) Te beginnen met 1 Julij 1875 mogen de bankeu hare reeds ingewisselde billetten beneden de $100 \mathrm{R}$. M. niet meer uitgeven. 
genoemde muntwet over de banken voorkomt, de nadere regeling werd aan de later in te dienen Rijksbankwet overgelaten.

Het is bekend, hoe de jaren 1872 en 1873 voor Duitschland op finantiëel gebied noodlottige jaren ziju geweest, hoe in Duitschland, na het eindigen van den Duitsch-Franschen oorlog en het afbetalen van de kolossale oorlogschatting, ondernemingen yan allerlei aard als 't ware als paddenstoelen uit den grond oprezen, die aan de kapitaalmarkt eischen deden, die onmogelijk door baar bevredigd konden worden en eindelijk tot bittere teleurstellingen hadden aanleiding gegeven.

Algemeen nu werden de banken voor een groot deel aansprakelijk gesteld voor de treurige gevolgen dier reusachtige zwendelarijen; men beweerde, dat zij door het geven van crediet op groote schaal, door de, ter wille van het hooge disconto, buitensporige uitgifte van banknoten (fictief kapitaal), aanleiding badden gegeven tot eene crisis, welker noodlottige gevolgen nog niet nitgewischt zijn ell die zich nog lang zullen doen gevoelen. Men bewoerde verder, dat, tengevolge van die te groote uitgifte ran banknoten, die den voorra:al van ruilmiddelen (reeds door de fransche milliarden zoo zeer vergroot) buiten verhouding met de behoefte had doen toenemen, de prijzen van alle loonen en levensmiddelen booger gestegen waren dan in eenig ander land ter wereld, en er derhalve eene wanverhouding ontstaan was tusschen productie en consumtie, die voor het groote publiek de rampzaligste gevolgen moest bebben. Geen wonder derhalve, dat men reikbalzend nitzag naar eene Rijksbankwet, die al die banken zou opruimen, die, naar men beweerde, ten nadeele van elken eerlijken handel en ten bate van zwendelarijen en buitensporige speculatiën strekken. Metverlangen werd die bankwet te gemoet gezien, die tabula rasi zou maken van alle banken, die de definitieve invoering van den gouden standased bemoeijelijkten en het land met papieren betaalmiddelen van allerlei aard overstruomden, aan wolker deugdelijkheid bij menigeen twijfel oprees. Niet onduidelijk werd tevens de wensch uitgesproken, dat de eenheid ook op het gebied van bankwezen zou tot stand komen, namelijk in zooverre, dat er slechts ééne bank, de Rijksbank, zou bestaan, die alleen de bevoegdheid zou krijgen om bankbilletten uit te geven.

In het begin van den afgeloopen zomer werd eindelijk het lang verwachte bankwetsontwerp door den Bondsraad openbaar gemaakt, dat echter in het geheel niet aan de zoo hoog gespannen verwachting voldeed. Talrijk waren de bezwaren, die er van alle 
kanten tegen dit ontwerp werden ingebragt. De eenheid ran het, baukwezen, warop men gehoopt bad, werd in bet ontwerp niet aangetroffen; vijf verschilleade soorten van banken zouden er ten gevolge van het ontwerp in Duitschland kunnen bestaan, allen met het regt om banknoten uit te geven, slechts daarin van elkander onderscheiden, dat de banknoten al of niet buiten de staten, waar zij concèssie hebben gekregen, circuleren mogen, naar gelang de banken aan sommige bepalingen der wet al dan niet voldoen. Een ander groot bezwar is, dat door het ontwerp slechts een provisioneele toestand voor den tijd van tien jaren in het leven wordt geroepen, zoodat, na dien tijd, aan de banken, wanneer zij zich zelfs an al de wettelijke bepalingen der bankwet hebben onderworpen, zonder schadeloosstelling het regt tot het uitgeren van banknoten kan worden ontnomen.

Bene andere bepaling van het ontwerp is, dat de banken slechts voor het $\frac{1}{4}$ van baar bedrag aan banknoten van $100 \mathrm{R}$. M. mogen uitgeven, de orerige $\frac{3}{4}$ mogen slechts bestaan in banknoten van 200,500 en $1000 \mathrm{R}$. M. benevens in de veelrouden van de laatsten, eene bepaling waardoor bet gebruik van bankbilletten voor het publiek moeijelijk, maar de toestand der banken in geen enkel oprigt zekerder gemaakt wordt. Volgens het ontwerp zal het bedrag der bankbilletten, niet door munt en muntmateriaal, rijkspapiergeld en banknoten van andere Duitsche banken gedekt, voor geheel Duitschland op 300 mill. R. M. vastgesteld worden, over de verschillende banken te verdeelen naar maatstaf van haren omloop aan banknoten gedurende de jaren 1867, 1868 en 1869, met dien verstande, dat zij voor dit niet gedekte bedrag jaarlïks 1 pCt., voor al hetgeen zij boven dit bedrag uitgeven 5 pCt. belasting moeten betalen. Bovendien mogen zij nimmer meer dan het drieroudige bedrag van hetgeen zij ann munt, muntmateriaal, rijksen bankpapier in kas hebben aan bankbilletten uitgeven. Het is het stelsel door de Engelsche bankwet van 1844 in praktijk gebragt, dat evenwel niet steekhoudend is gebleken, daar het gedurende de crisisjaren 1847,1857 en 1866 fiasco beeft gemaakt en, door de schorsing van de Peelwet, buiten werking moest worden gesteld.

In Duitschland wil men nu, door deze zoogenaamde contingentirung der banknoten, de al te ruime uitgifte van banknoten tegengaan, omdat men daaraan voornamelijk de rasse stijging der prijzen van levensmiddelen en arbeidsloonen als ook den grooten uitroer van goud toeschrijft. Door cijfers beeft wen echter in den laatsten 
tijd aangetoond, dat do gezaminlijke circulatie van bankbilletten in Duitschland (zoo gedekte als ongedekte) in September veel hooger was, dan in de tijden van de ergste crisis (Mei 1873) namelijk 4:25 mill thaler tegen vrooger 396 mill. thaler, en daarnit beeft men het bewijs geput, dat de groote uitgifte vau banknoten niet de oorzaak is geweest, noch van de hooge prijzen van leveusmiddelen en loonen, daar deze in het laatste jaar belangrijk gedaald zijn, noch van den grooten uitvoer van goud uit Duitschland, uithoofde het laatste de schuld is van de Duitsche Regering zelve, die het nieuw gemunte goudgeld in circulatie boeft gebragt, vóórdat do munthervorwing volbragt en bet overvloedige goedkoopere zilver gedsmouetiseerd was.

Keeres wij na deze uitweiding weer naar het Congres terug 'n gaan wij eens na, hoe dit onderwerp daar beproken werd. Drie resolutiën waren aan het oordeel van het Congres onderworpen geworden, en alle drie werden zij door de voorstellers up bet Congres verdedigd. Het waren de heeren Dr. Alexander Meijer van Berlijn, Prof. Soetbeer van Göttingen, eene erkende autoriteit op het gebied van het munt- en bankwezen in Duitschland en L. F. Seyffardt van Crefeld. De resolutie van Dr. Al. Meijer was van deu volgenden inhoud:

1. Het bankbillet vervalt in het hedendaagseh maatschappelijk verkeer de taak : a. Bețalingen pan een groot bedrag en op verre if itianden te vergemakkelijken, daar nu bet aftellen en verzenden van groote bedragen metail onnoodig wordt; $b$. de slingeringen in de beboefte ann ruilmiddelen, die van dag tot dag voorkomen, op eene snellere en goedkoopere wïze te vereffenen, dan dit door uitbreiding en inkrimping van den metalvoorraad mogelijk is.

2. Ten gevolge van de historische ontwikkeling onzer mantschappelijke toestanden is bet onmogelijk, om de nitgifte van bankbilletten plotseling te verbiedeu of geheel en al vrij te laten.

3. Eene uitbreiding ran de uitgifte van bankbilletten moet verboden worden, omdat dit een nadeeligen invloed op de stijging der prijzen uitoefent, en de agiotage bevordert; integendeel is wegens de op handen zijnde invoering van den gouden standaard de inkrimping aan te berelen.

4. Deze beide doeleinden kunnen slechts bereikt worden, hetzij door eeu direct verbod van uitgifte boven een zeker bedrag, hetzij toor die uitgifte door eene belasting moeijelijk te maken.

Die resolutie werd op de volgende wïze toegelicht.

Reeds dikwijls bebben de volkshuishoudkundige congressen zich 
met het bankwezen bezig gehouden; cene geheele recks van vragen komen hierbij te pas, die het best één voor één en na elkaâr besproken worden.

Vóór 1866 was de staatkundige verbrokkeling de oorzak, dat de wetgeving op dit gebied magteloos moest wezen; wij moesten or ons toe bepalen, ons slechts tot den handelstand te wenden, om hem in te lichten over de taak en het doel van het kapitaal en het crediet, om de vele dwaalbegrippen, die er op dit gebied bestonden, aan te toonen. In het jaar 1870 kregen wij de wet op de naamlooze vennootschappen, dus ook de vrïheid om banken op te rigten, die alles doen kunnen, slechts geen bankbilletten uitgeven. De bankbillettenkwestie is derhalve voor de wetgeving de hoofdzank. De eerste vraay is derbalve: wie zal het regt hebben, om banknoten . uit te geven? de tweede vragg: zal die bevoegdbeid aan particulieren dan wel aan eene Rijksbank alleen worden verstrekt? $\mathrm{Hij}$ zelf zou de eerste vraag aldus willen geformuleerd hebben: onder welke voorwaarden zal men het regt hebben, om bankuoten uit te geven? Hij wenschte het bereids verschenen ontwerp eener baukwet niet te bespreken, bij wilde zelfs, om geene verdeeldheid tusschen berriende elementen te veroorzaken, de kwestie eener Rijksbank geheel buiten spel laten, hij wildo zelfs den wensch daarnaar geheel opofferen, zoo hij slechts de contingentirung (bepaling ran het bedrag der ongedekte bankbilletten) daarvoor verkrijgen kan. Hij gelooft niet aan de onontbeerlijkheid der bankbil]etten: het vergemakkelijken der betalingen kan door andere vormen vas crediet worden verkregen (de spreker bedoelde girobanken, clearinghouses enz.); van meer belang is do functie dẹr bankbilletten als regulateur der circulatiemiddelen, omdat de uit het verkeer teruggenomen banknoten geene kosten veroorzaken, zij zijn, in matig bedrag voorhanden, buffers, bestemd om de hevige stooten der slingeringen van het crediet te breken. Zoomin als eane plotselinge vrijlating in de uitgifte vau bankbilletten aanbevelenswardig is, omdat de praktijk tot eene beperkte rrijheid bad geleid, even zoo min was het mogelijk ze geheel uit het maatschappelijk verkeer to verbannen. Hij hield het er voor, dat de zilveren standaard do overmatige uitgifte van bankbilletten heeft bevorderd, bij den gouden standaard was do behaefte daaraan van zelf zoo groot niet meer. Maar zelfs bij deu zilveren standaard zou hij eene inkrimping der banknotell wenschelijk hebben geacht, opndat, hoewel faillissementen van bauken zelfs in kritieke tijdon in Duitschland niet zijn voorgekomen, do 
soliditeit van het maatschappelijls verkeer daardoor geleden heeft. Eene vergelijking tusschen Frankrijk en Duitschland toont ginds een grooten, daar een kleinen metaalvoorraad, ginds weinige, daar vele ongedekte banknoten, ginds zeer ligte, daar zeer hevige crisissen.

Door de bovenmatige uitgifte van bankbilletten in Duitschland kon men gemakkelijk crediet verleenen en daardoor juist onvoorzigtige ondernemingen begunstigen, die tot handelscrisissen aanleiding geven. Iedere groote crisis berust op eene dwaling, namelijk betreffende den voorraad van aanwezig kapitaal. De op crediet gebaseerde ondernemingen vinden geen steun in de groote hoeveelheid ongedekte-banknoten. Vele meenen nu wel, dat de circulatiebanken juist in kritieke tijden an den handelstand tot steun verstrekken en daarom niet beperkt moeten worden in de uitgifte van billetten. Maar geene inrigting kan meer kapitaal uitleenen dan zij beeft. Waar dit beginsel verloochend wordt, rigt men slechts onheil aan. Het is juist de pligt der banken om, door bij tijds het disconto te verboogen, hot publiek te waarschuwen, dat de voorraad kapitaal verminderd is, en met kracht moeten zij dit doen, maar dit niet zoeken te bemantelen door meer banknoten uit te geven; juist daarom moet de wet de inkrimping van de uitgifte der bankbilletten bevelen. Het is het stelsel der Engelsche bankwet van Sir Robert Peel, maar op indirecte wijze in toeprssing gebragt, en dit wil de Rijksbankwet door de uitgifte van ongedekte banknoten te belasten. De uitgifte van banknoten wordt dusdoende getemperd. Niet plotseling zal in kritieke tijdsomstandigheden het uitgeven van banknoten gestaakt, maar zij zullen nog uitgegeven mogen worden tegen een, met de tijdsomstandigheden overeenkomenden, hoogeren prijs. Dit zal veel beter werken, dan de directe contingentirung. $\mathrm{Wij}$ willen de buitensporige uitgiften van papieren betaalmiddelen, die aan de zwendelaars de middelen voor hunne speculatiën verschaffen, tegengaan, want zelfs groote circulatiebanken hebben niet altijd aan de verlokking der speculatie weerstand kunnen bieden. Wat het vaandel is voor den soldaat, is de metaalvoorraad voor den bandelstand, daarom moet deze zich scharen, opdat de geldcirculatie in bet land de grootste zekerbeid zal hebben en dat is onmogelijk, als zelfs ééne enkele bank in het land het regt zal hebben, om onbeperkt banknoten te mogen uitgeven.

De beer Seyffardt van Crefeld was van een ander stelsel uitgegaan, Deze had reeds op den vijfden Duitschen Handelsdag te Leipzig, 
den 13 Mei 1872, het beginsel verdedigd, om zoo spoedig mogelijk tot het opheffen van de particuliere cireulatiebanken over te gaan, daarvoor de Pruissische bank in eene Centrale Rijksbank to herscheppen, wier niet door metaal gedekte billetten ook op een maximum bepaald moeten worden. Aan dit beginsel was hij trouw gebleven, echter met het onderscheid, dat de particuliere banken zouden blijven bestaan, onder voorwaarde, dat zij in 't geheel geene ongedek to banknoten zullen uitgeven; hij had dit, in eene resolutie geformuleerd, aan het oordeel van het Congres onderworpen. Hij beweerde o. a., dat door de som van 147 mill. thalor ongedekte banknoten, die in Duitschland circuleren, de prijzen van alle voortbrengselen gestegen en de ruilmiddelen gedepreciëerd waren, de depreciatio zal nog wel verder gaan en eindelijk ten gevolge hubben, dat men slechts met fictieve wuarden zal hebben te rekenen.

De vrees is niet overdreven, dat dit bij nationale rampen of eene groote crisis de noodlottigste gevolgen na zich zal siepen; staking van betaling der circulaliebanken en groote verwarring in het geldverkeer zullen hierdoor ontstaan. Hij wees er op, boe in 1866, bij het nitbreken van den Oostenrijksch.Pruissischen oorlog, niemand zelfs Pruissische bankbilletten had willen aannemen; daarom wil hij niets van ongedekte banknoten weten. Hij hoopte op het toenemen der depositobanken, van het checksysteem, van de clearinghouses. Niet de particulieren maar de Staat beeft roor circulatiemiddelen te zorgen. Hij verdedigde ten slotte de oprigting eener Rijksbank, toonde aan, dat het nog een overblijfsel van het particularismus was, dat velen zich tegen de Rijksbank aankanten en dat het voor de Zuidduitsche Staten en de Hanzesteden evenmin noodlottig zou zijn, als er eene Centrale Bank te Berlijg bestond, als het nu voor Breslau, Koningsbergen en Keulen hinderlijk was, dat Berlijn de Pruissische bank bezat.

Professor Soetbeer van Göttingen had reeds, v6ór dat het ontwerp der bankwet bekend was, eene resolutie voor het Congres gereed gemaakt, waarin hij van het denkbeeld uitging, dat eene Rijksbank zoude worden opgerigt naast andere banken, die daartoe de autorisatie moeten bebben; dat $\frac{1}{3}$ der aitgegeren billetten door munt of muntmateriaal, en de overige $\frac{2}{3}$ door gedisconteerde wissels moeten gedekt zijn. $\mathrm{Na}$ de publicatie van het bankwetsontwerp trok hij zijne vorige resolutie terug en stelde eene andere voor, waarin hij de niet-toepasselijkheid van het ontwerp op de op to te rigten Rijksbank wenschelijk verklaarde en voor de audere 
banken de reeds genoemde dekking benevens de belasting op de ongedekte banknoten van 1 tot 5 pCt. verlangde. Do resolutie bevatte tevens eene reeks ran voorschriften voor de Rijksbank, van welke de voornanmste waren, dat de Pruissische bank in eene Rijksbank zou yeranderd worden, met een door particulieren bijeen te brengen stamkapitaal van 120 mill. R. M., dat de onged rkte bankbilletten in gewone omstandigheden op zijn hoogst 240 mill. R. M. zouden mogeu bedragen, tat men deze bank met de uitgifte van Rijkspapiergeld moest belasten en aan de bankbilletten het karakter van wettig betaalmirldel geven, zoolang zij geregeld door de Rijksbank verzilverd worden.

Prof. Soetbeer bad eene tabel gereed gemaakt, waarop de 34 verschillende circulatiebanken van Duitschland waren vermeld met haar stamkapitaal, den duur harer concessie, het bedrag der.banknoten die zij mogen uitgeven, hare circulatie aan bankbilletten op het einde van het jaar 1873, hare metaaldekking op dit tijdstip, benevens het bedrag harer ongedekte bankbilletten. Daaruit bleek o. a., dat er banken waren, zooals die van Dessau, Sondershausen en Bremen, die eene concessie hebben voor onbeperkten tijd, anderen wederom, zooals die van Brunswijk, Meiningen, Gotha, Gera, Bückeburg, wier concessie eerst afloopt, respectievelijk in de jaren 1952, 1956,1946, 1953 en 1956, dat de drie laatstgegenoemden met een stamkapitaal, respectievelijk van 1,800,000, $2 \frac{1}{2}$ en 2 mill. thaler het regt hebben, om tot een onbegrensd bedrag aan banknoten uit te geven en dat bet gezamenlijk bedrag van banknoten, op ult. Dec. 1873 in circulatie, bedroeg 450,081,389 thaler, waarvan slechts 302,501,654 door metaal waren gedekt.

Prof. Soetbeer wenschte; dat men zich niet in theoretische bespiegelingen verdiepen, maar zich op een praktisch standpunt stellen, alzoo het bankwetsontwerp behandelen zou; hij wees er op, hoe de wetgering de rroegere besluiten van het Congres, betreffende den dubbelen standaard, de afschaffing van den thaler als rekeningeenheid, en het invoeren van den gouden standaard had bekrachtigd. Hij verklaarde zich tegen de belasting van $1 \mathrm{pCt}$. op de ongedekte banknoten, daardoor zou het disconto in Duitschland hooger worden dan in andere landen, bandel en industrie moeten daaronder lijden. $\mathrm{H}_{\mathrm{ij}}$ meende, dat $1 \mathrm{pCt}$. voldoende was, terwijl hij zich voor het overige bij de $5 \mathrm{pCt}$ bolnsting zou neêr. leggen. Hij gaf toe, dat de voorwaarde, dat een derde door metaal moest gedekt zijn (Dritteldeckung), willekeurig was, maar door het gebruik geijkt. Hij meende, dat de verandering ran de Pruis- 
sische in eene Rijksbank geene zwarigheid hebben kon, evenmin als de verleening van het karalter van wettig betaalmiddel aan de billetten der Rijksbank, zoolang zij tegen geld inwisselbaar zijn. Hij betreurde eindelijk, dat diezelfde bepaling niet voorkomt in de wet op het Rijkspapiergeld, omdat dit in kritieke tijden eene papiek kan tegenhouden on men niet noodig $y_{\text {al }}$ bebben den gedwongen koers en de oninwisselbaarheid der bankbilletten te decreteeren.

Door een ander spreker, den bankier Meyersfeld van Brunswijk, werd eene lans gebroken voor de partikuliere circulatiebanken, waaraan vele takken van nijverheid baren bloei bebben to danken gehad; zoo wees bij er op, hoe de beetwortelsuikerfabrieken in de omgeving van Maagdenburg aan de Brunswijker bank hare opkomat verschuldigd zijn.

De heer Dr. Ludwig Bamberger, een der uitstekendste leden van den Duitschen Rijksdag, bekend door rijne geschriften over bank- en muntwezen, hield verrolgens eene schitterende improvisatie, die langer dan een half uur duurde, warin hij zich ten gunste eener Rijksbank en tegen het contingenteren der uit te geven bankbilletten verklaarde. Hevig voer hij uit tegen de kleine circulatiebanken, die door de miniatuursouvereinen van Duitschland (Gott- und rechtloser Souveränitäts Schwindel, zooals Bismarck zich eens had uitgedrukt) privilegiën voor den tijd van honderd jaren hadden gekregen. $Z_{0 o}$ is br. de Meiningsche bank niets anders dan een credit mobilier met het regt om gedurende honderd jaren banknoten te mogen uitgeren, omdat misschien de kamerheer van den bertog van Meiningen en een Frankforter bankier op dit denkbeeld gekomen waren. Hij wilde daarom eerst op minnelijke wijze de banken trachten over te balen, om van hare concessie afstand te doen, en zou dit niet ging, met geweld te werk gaan. Hij wenschte, dat de Pruissische bank hasr kapitaal van 21 mill. thaler in de Rijksbank zou inbrengen, hoewel het stamkapitaal van de bank eene ondergeschikte rol speelt, bet dient slechts als waarborgfonds; de Engelsche en Fransche banken hebben geen stamkapitaal, zij hebben dit aan de Regering geleend.

Ools alle voorschriften betreffende de dekking eijn nutteloos, zoolang er geen gouden standaard is, omdat niemand aan de banken het zilver afnemen zal en het goud niet aanwezig is. Hij wenscht daarom, dat aan de Rijksbank moest opgedragen worden, tegen. vergoeding van het te lijden verlies, binnen vijf jaren 100 tot $200^{\circ}$ mill. thaler aan zilver uit den omloop te trekken en daarroor goud in circulatie te brengen. 
De heer Julius Faucher, rigtte zijne bedenkingen hoofdzakelijk tegen de bewering van den heer Bamberger, dat het kapitaal eener bank geheel buiten aanmerking kon blijven. Reeds uit het oogpunt van publieke moraliteit was hij tegen ongedekte banknoten. $\mathrm{Hij}$ vergeleek het ongedekte bankbillet bij valsche munt, die, zoolang zij niet ontdekt wordt, dezelfde dienst bewijst als het geld, zij vergenakkelijkt het verkeer en bevordort de nijverheid, slechts de eorste maal, dat zij wordt uitgegeven, is het geen verbruik zonder roldoende voortbrenging. Het bankbillet wordt uitgegeven als eene aanwijzing op aanwezige voorraden, maar het is niet terens eene kwitantie voor bewezen diensten. Het wordt door de bank uitgegeven die den dienst nog niet bewezen heeft, de bank belooft dit slechts roor den tijd, dat zij het billet inwisselt. Hij noemde hot uitgeven van ongedekte banknoten een inbreuk op het nationaalvermogen, en daarom moet in alle beschaífde landen daaraan paal en perk worden gesteld, zoo goed als aan het vervaardigen van valsche munt.

Nadat nog eenige andere sprekers het woord gevoerd en de heeren prof. Soetbeer en Seyffardt hnnne resolutie ingetrokken hadden, werd het voorstel van Dr. Alex Meijer aangenomen met de bijvoeging in no. 2 , dat de verandering van de Pruissische bank in eene Rijksbank en de opheffing van alle particuliere banken moet plaats grijpen.

De voorstanders eener Rijksbank hadden dus gezegevierd, het bestaan eener zoodanige instelling was reeds lang een desideralum in Duitschland geweest en men wilde dit niet langer een vrome wensch doen blijven. Tot staving daarvan kunnen wij nog op den laatsten Duitschen Handelsdag van October jl wijzen, waar hetzelfde onderwerp ter sprake kwam, en war alle sprekers zich ten gunste eener Rijksbank hadden verklaard, hoofdzakelijk op grond, dat de nieuwe standard door die bank beter tot stand zal komen en te regter tijd bet wegstroomen van het Duitsche goudgeld naar het buitenland zal worden tegengegaan, maar, in de eerste plaats, wegens den invloed op het bankwezen. Ook daar sprak men van den verderfelijken invloed der bankbilletten op den handel; men rond het goed, dat alle particuliere banken onder den duim der rijkswetgeving zouden komen. Men noemde het goellkoop disconteren, door middel der banknoten, een ongezonden toestand, omdat papier geen kapitaal is en geen kapitaal te voorschijn roept; daaraan schreef men ook de overspeculatie der laatste jaren toe, oudat de banknoten tot allerlei ondernemingen werden verstrekt, 
als waren de banken conmanditaire rennooten. Ook de Duitache Rijksdag beeft onlangs duidelijk genoeg te kennen gegeven, dat bij het met bet Crefeldor Congres en den Duitschen Handelsday betreffende de oprigting eener Rijksbank eens is, want, bij de openbare behandeling van het bankwetsontwerp, is het verlangen naar de oprigting eener zoodanige bank zoo duidelijk te kennen gegeven, dat de Bondsraad bet ontwerp teruggetrokken beeft, ten einde er de verlangde wiziging in te brengen. $\left({ }^{*}\right)$

En hiermede was de arbeid van het Congres vocr dit jaar ten einde gebragt. Het Congres had getoond, dal, hoezeer het getrouw bleef aan zijn leus van vrijbeid, men toch niet blind was voor de nadeelen, dio de vrijbeid, als er misbruik van gemaakt wordt, voor het maatschappelijk verkeer kon hebben. Men heeft zeer goed ingezien, dat de taak van den Staat niet langer uitsluitend bestaat in bet verschaffen van veiligheid tegen den vijand van buiten en van binnen, maar dat bij handelend moet optreden overal, waar de maatachappij slechts in en door den Staat haar doel kan bereiken. Maar daarin onderscheidt zich bet Volkshuishoudkundig Congres van zijn jongeren broeder te Eisenach, dat deze (vooral in den beginne, want men is reeds een weinig van het oorspronkelijk programma teruggekomen) den Staat overal en in alles roorop schuift, terwijl het Volkshuishoudkundig Congres hem eerst in bet gewone maatschappelijk verkeer de tweede plaats toewijst. De tijd zal leeren, welk beginsel het beste is en de bovenhand houden zal.

Vragen $\times$ ij naar het nut van dergelijke congressen, dan gelooven $w i j$, dat het tweeledig is. Het is niet alleen een middel, om gelijkgezinde mannen van dezelfde rigting bijeer te brengen on ben in do gelegenheid te stellen, met elkaâr van gedachten to wisselen over belangrijke economische en sociale onderwerpen, maar iij kunnen ook strekken, om gewigtige rraagstukken te behaudelen, die door de publieke opinie aan de orde van den dag gesteld zijn, hunne besluiten kunnen dan als zoovele vingerwijziugen voor de Regering en de vertegenwoordigende ligchamen worden beschouwd, die voor staatsbestuur en wetyeving tot leiddraad mogen strekken. Wij kunnen ons dan ook niet vereenigen met de woorden van een Engelschen journalist, door Prof. Guffcken te Stratsbury aangehaald in zijne brochure Das Deutsche Reich und die Bankfrage:

(*) Sedert is het Deutsche Bankgesetz van 14 Maart 1875 tot stand gekomen, houdende iustelliug eener enkele Rijksbank, met bepaliugen nopens de private circulaticbanken.

ECON. 1875. 
„These congresses consist much in that habit for soleinn gossip "in public, which seeme to have taken bold of the present gene. „ration." Prof. Geffcken onderschrijft deze meening en ontkent do competentie ran die congressen, om over belangrijke vraagstukken te beslissen, omdat iedereen toch voor weinig geld lid van bet congres worden kan, en de vooraf beraamde besluiten van eenige leiders altijd aangenomen worden, zoodat men daaraan niet het minste gewigt mag toeschrijven, en zij niet te beschouwen zijn als de uitspraken van staathuishoudkundige autoriteiten. Wij gelooven dat dit gevoelen van sterke overdrijvin pleiten, dat wel is waar een gedeelte van het congres bestaat uit bewoners van de plaats, waar de zitting wordt gehouden en van hare omstreken, maar dat toch, waar in eene vergadering van 240 personen ongeveer 100 gevonden worden uit verschillende oorden van Duitschland bijeengekomen, onder welke voor het grootste deel mannen die door. hunne gesebriften en bunnen werkkring zich een welverdienden naam hebben verworven, dat daar niet gesproken kan worden van eene vereeniging, die incompetent zou zijn on een oordeel uit te brengen. Het Volkshuishoudkundig Congres is, zooals wij in den loop onzer beschouwingen bebben medegedeeld, menigmaal de aanleiding geweest tot belangrijke verbeteringen op economisch gebied. Moge het dit tot beil van het jeugdige Duitsche Rijk nog dikwijls doen, omdat in eene consolidatie der economische belangen de eenige waarborg gelegen is, dat dit Rijk zich op den duur op de werken des vredes zal blijven toeleggen!

Leeuroarden, Dec. 1874.

Mr. S. J. CohEN. 